\title{
Aqueous leaf extract of guava: a non-toxic male fertility booster
}

\author{
Ekaluo $^{1}$, U.B., Erem ${ }^{1}$, F. A., Omeje ${ }^{2}$, I.S., Ikpeme ${ }^{1}$, E. V., Ibiang ${ }^{1}$, Y.B. and \\ Ekanem. ${ }^{3}$ B.E. \\ ${ }^{1}$ Department of Genetics and Biotechnology, University of Calabar, Calabar, Nigeria. \\ ${ }^{2}$ Department of Animal Science. Delta State University, Asaba Campus, Asaba, Nigeria. \\ ${ }^{3}$ Department of Science and Technology, Akwa Ibom State Polytechnic, Ikot Osurua, Nigeria.
}

\begin{abstract}
Effect of aqueous leaf extract of guava on level of some sex hormones and fertility was studied in albino rat as a mammalian model. The male rats were divided into four groups of six rats each. The rats were administered with guava leaf extract at 0,100,200 and $300 \mathrm{mg} / \mathrm{kg} \mathrm{BW}$ respectively for 70 days. The results showed dose-dependent significant $(P<0.01)$ increases in levels of LH/ICSH, FSH and testosterone. There was also a positive relationship between conception rate, number of offspring and average litter size. Hence, aqueous extract of guava leaf could be used as male fertility booster without toxic side effects.
\end{abstract}

Key words: Guava, serum sex hormone, testosterone, FSH, LH/ICSH, fertility.

\section{Introduction}

Guava (Psidium guajava L.) has been extensively studies in terms of pharmacological activity of its major components [1]. Toxicity studies of guava in mice and other animal models as well as controlled human studies show that its fruit, leaf and root are safe and without side effect [2]. The leaf decoction is taken as a remedy for throat and chest ailments [3], cough, pulmonary diseases, anti-inflammatory and homeostatic agent [4]. It is also taken as an emmenagogue and vermifuge and treatment of leucorrhea [3, 4].

In folk medicine, especially in some traditional African localities, decoctions from guava leaves are used in traditional treatments against diabetes, malaria [5], also as a tonic to treat digestive conditions and gastrointestinal disorder [6], because of it astringency; crushed leaves are applied on wounds, ulcers and rheumatic places. The leaves are also chewed or gargled to relieve oral ulcer, toothache and inflamed gums [4]. In practice, guava leaf extracts are particularly believed to improve erection, treat impotency and sexual dysfunctions in males. However, there is paucity of written evidence to support this claim [7].

Reductions in levels of testosterone and follicle stimulating hormone (FSH) have been responsible for suppressed potency, hormonal imbalance and sexual dysfunctions in males [8, 9]. This study set out to explore the effect of aqueous leaf extract of guava on the levels of the following reproductive hormones: testosterone, follicle stimulating hormone (FSH), luteinizing hormone/interstitial cell stimulating hormone (LH/ICSH), estradiol and prolactin; in male rats as a model.

\subsection{Plant materials}

\section{Materials And Methods}

Guava leaves were collected from the botanical garden of the Botany Department, University of Calabar, Calabar. The leaves were sun-dried and pulverized into fine powder.

\subsection{Experimental animals}

Ninety six healthy adult albino rats (24 males and 72 females) of 60 to 70 days old were used. The males were divided into 4 groups of 6 animals each in a Complete Randomize Design (CRD) and housed in conventional wire mesh cages.

\subsection{Experimental procedure}

The rats were administered with aqueous leaf extract of guava at $0,100,200$ and $300 \mathrm{mg} / \mathrm{kg} \mathrm{BW}$ respectively for 70 days. On the sixty sixth day of treatment, both the treated and control males were allowed to sire the untreated females in a ratio of 1 male: 3 females for 4 days. The experimental animals were allowed free access to water and commercial feed throughout the period of the experiment. Generally, the study was conducted in accordance with the recommendation from the declarations of Helsinki on guiding principles in care and use of animals. The males were anesthetized in chloroform vapour and blood samples were collected through cardiac puncture for hormonal assay $[10,11]$. The sired female rats were used for determination of fertility (conception) rate $[12,13]$. 


\subsection{Collection of data and analysis}

Data were analyzed statistically using the completely randomize design (CRD) and Significant differences were separated using least significant difference test.

\subsection{Hormones}

\section{Results}

The results obtained from the administration of guava leaf extract on rat showed that the test substance had dose-dependent effects on LH/ICSH, FSH and testosterone. LH/ICSH was significantly increased from group B $(100 \mathrm{mg} / \mathrm{kg} \mathrm{BW})$ to group D $(300 \mathrm{mg} / \mathrm{kg} \mathrm{BW})$. FSH and testosterone were significantly different from group C (200mg/kg BW) to group D (300mg/kg BW) when compared with their control values. Whereas there was no significance $(\mathrm{P}>0.05)$ observed in the levels of estradiol and prolactin. Table 1 shows the effect of aqueous extract of guava leaf on reproductive hormones of male rats.

\subsection{Fertility test}

The result show an increase in the conception rate which ranged from $50 \%$ in the control group to $83.33 \%$ in group D $(300 \mathrm{mg} / \mathrm{kg} \mathrm{BW})$, as well as the number of offspring increasing from 26 in the control group to 63 in group D $(300 \mathrm{mg} / \mathrm{kg} \mathrm{BW})$. There were dose-dependent and proportional increases in conception rate, number of offspring and average litter size as shown in Fig. 1.

Table 1: Effect of aqueous extract of guava leaf on reproductive hormones of rats

\begin{tabular}{lrrrrr}
\hline Parameter & $\begin{array}{c}\text { Group A } \\
(\mathbf{0 ~} \mathbf{~ m g} / \mathbf{k g ~ B W})\end{array}$ & $\begin{array}{c}\text { Group B } \\
(\mathbf{1 0 0} \mathbf{~ m g} / \mathbf{k g ~ B W})\end{array}$ & $\begin{array}{c}\text { Group C } \\
(\mathbf{2 0 0} \mathbf{m g} / \mathbf{k g ~ B W})\end{array}$ & $\begin{array}{c}\text { Group D } \\
(\mathbf{3 0 0} \mathbf{m g} / \mathbf{k g ~ B W})\end{array}$ & $\begin{array}{c}\text { LSD } \\
\text { value }\end{array}$ \\
\hline LH/ICSH (mIu/ml) & $6.96^{\mathrm{a}} \pm 0.18$ & $8.02^{\mathrm{b}} \pm 0.28$ & $8.04^{\mathrm{b}} \pm 0.12$ & $8.70^{\mathrm{b}} \pm 0.34$ & 0.89 \\
FSH (mIu/ml) & $1.60^{\mathrm{a}} \pm 0.07$ & $1.90^{\mathrm{a}} \pm 0.04$ & $2.16^{\mathrm{b}} \pm 0.02$ & $2.62^{\mathrm{b}} \pm 0.19$ & 0.45 \\
Estradiol $(\mathrm{ng} / \mathrm{ml})$ & $0.17^{\mathrm{a}} \pm 0.01$ & $0.16^{\mathrm{a}} \pm 0.02$ & $0.20^{\mathrm{a}} \pm 0.04$ & $0.18^{\mathrm{a}} \pm 0.03$ & - \\
Testosterone $(\mathrm{ng} / \mathrm{ml})$ & $5.22^{\mathrm{a}} \pm 0.19$ & $6.06^{\mathrm{a}} \pm 0.52$ & $6.88^{\mathrm{b}} \pm 0.49$ & $7.06^{\mathrm{b}} \pm 0.34$ & 0.94 \\
Prolactin $(\mathrm{mIu} / \mathrm{ml})$ & $222.40^{\mathrm{a}} \pm 7.35$ & $281.6^{\mathrm{a}} \pm 24.28$ & $244.00^{\mathrm{a}} \pm 13.79$ & $274.80^{\mathrm{a}} \pm 39.41$ & - \\
\hline
\end{tabular}

${ }^{\mathrm{ab}}$ Values across the table with the same superscript are not significantly different based on ANOVA.

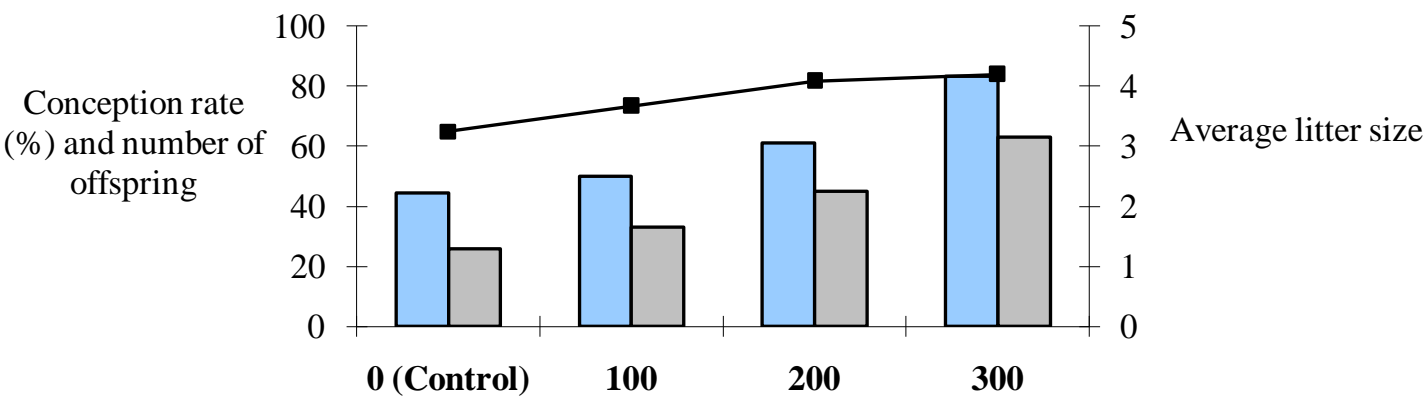

Concentration of guava leaf extract $(\mathrm{mg} / \mathrm{Kg} \mathrm{BW})$

$\square$ Conception rate $\square$ Number of offspring

$\rightarrow$ Average litter size

Figure 1: Relationship between aqueous extract of guava leaf on conception rate, number of offspring and average litter size in rats

\section{Discussion}

The aqueous extract of guava leaf has been shown to have a higher potency in enhancing the release of LH, FSH and testosterone into the blood stream. This was attributed to the effect on the accessory sex organs $[14,15,16]$ and positive influence on the gonadotropins releasing hormones $(\mathrm{GnRH})$ in stimulating the anterior pituitary to produce the gonadotropins hormones (FSH and LH/ICSH). FSH and LH stimulate the testes to produce testosterone. Uboh et al. [7] reported that guava leaf extract induced increase testosterone and no change in the level of LH and FSH in rats. According to Gelain et al. [8] and Greenspan and Strewler [9], LH/ICSH stimulates the interstitial cells (Leydig cells) of the testes to increase testosterone production. The dose-dependent increases and the relationship between conception rate, number of offspring, average litter size are indications of the profound positive effects of aqueous extract of guava leaf on serum sex hormone [7, 17, 18], especially LH/ICSH, FSH and testosterone. This affirms the report of Kamath et al. [2] on the non-toxicity 
of aqueous leaf extract of guava. Hence; it is recommended that guava leaf extract could be used as male fertility booster without any toxic side effects.

\section{References}

[1] Nwiyi, O.C., Chinedu, N.S. and Ajani, O.O., (2008). Evaluation of antibacterial activity of P. guajava and Gongronema latifolium. Journal of Medicinal Plants Research, 2 (8):189-192.

[2] Kamath, J.V.; Rahul, N.; Ashok-Kumar, C.K. and Lakshmi S. M. (2008). Psidium guajava: A review. Journal of Green Pharmacology, 2:9-12.

[3] Gutierrez, R.M., Mitchell, S. and Solis, R.V., (2008). P guajava :a review of its traditional uses, phytochemistry and pharmacology. Journal of Ethnopharmacology, 117(1):1-27.

[4] Goncalves, J.L., R.C. Lopez, D.B. and Oliveira, S. (2005). In vitro anti-rotavirus activity of some medicinal plants used in Brazil against diarrhea. Journal of Ethnopharmacology, 99:403-407.

[5] Pamplona-Roger, G. D. (1999). Encyclopedia of medicinal plants. Madrid: Editorial Safeliz

[6] Conde-Garcia, E.A., Nascimento, V.T. and Santiago-Santos, A.B. (2003). Inotropic effects of extract of Psidium guajava L. (guava) leaves on the guinea pigatrium. Brazilian Journal Medicine and Biological Research., 36: 661-668.

[7] Uboh, F.E.; Edet, E. E.; Eteng, M. U. and Eyong, E. U. (2010). Comparative effect of aqueous extract of P. guajava and ascorbic acid on serum sex hormones levels in male and female rats. Journal of Applied Science and Research, 6(4): $275-279$.

[8] Gelain, D. P.; Casali, E. A. and Dal-Pizzol, F. (2005). Effect of follicle stimulating hormone and vitamin A upon purinergic secretion by rats setoli cell. Molecular Cell Biochemistry, 278: 185-195.

[9] Greenspan, F. S and Strewler, G. J. (1997). Basic and clinical endocrinology-New York: McGraw Hill.

[10] Ekaluo, U.B.; Udoh, P.B.; Ikpeme, E. V. and Udensi, O. (2011). Effect of soybean (Glycine max L.) on the hormonal milieu of male rats. Pakistan Journal of Biological Sciences, 14: 752-754.

[11] Ekaluo, U.B.; Udoh, P.B., Ndome, C.B.; Ekpenyong, E. and Ikpeme, E. V. (2011). Effect of processed horse eye bean (Mucuna urens L.) on the hormonal milieu of male rats. International Journal of Recent Scientific Research, 2: 243-245.

[12] Ikpeme, E.V.; Udensi, O.; Ekaluo, U.B.; Uyoh, E.A.; Asuquo, B.O.; Udoh, F.V. and Udoh, P.B. (2007). Effect of crude extract of Carica papaya seeds on the reproductive efficiency of male albino rats. Global Journal of Pure and Applied Sciences 13: 365-368.

[13] Ikpeme, E.V.; Udensi, O.; Ekaluo, U.B (2012). Fertility activities of female rats via male rats administered with crude extracts of seed, leaf and pulp of Carica papaya (Linn). Elixir Applied Botany, 46: 8181-8184

[14] Londonkar, R. L.; Reddy, P. S.; Patil, S. R.. and Patil, S. B. (1998). Nicotin induced inhibition of the activities of accessory reproductive ducts in male rats, Journal of Ethnopharmacology, 60: 215-221.

[15] Londonkar, R. L.; Sharangouda, and Patil, S. B. (2008). Morphine induced inhibition of the activities of accessory reproductive ducts in male rats, Journal Experimental Medicine, 8: 67-72.

[16] Londonkar, R. L.; Sharangouda and Patil, S. B. (2009). Antifertility activity and phytochemical studies of Pergularia daemis leaves in male albino rats. Annual Indian Journal Natural Production, 5:45-49.

[17] Meistrich, M. L.; Finic, M.; Dacumha, M. F.; Hocker, U. and Ann, W. W. (1982). Damaging effect of fourteen chemotherapeutic drugs on mouse testis cell. Cancer Research, 10: 122-131.

[18] Gupta, R. S.; Kachawa, J. B. and Chandhary, R. (2004). Anti-fertility effect of methanolic pod extract of Albizzia lebbeck: Asian Journal of Andrology, 6: 155-159. 